Research article

\title{
Changes in fatty acid biosynthesis in marine microalgae as a response to medium nutrient availability
}

\author{
Tomásia Fernandes a , Igor Fernandes a ${ }^{\text {, }}$ Carlos A.P. Andrade ${ }^{\text {b,c }}$, Nereida Cordeiro a,* \\ a University of Madeira, Faculty of Sciences and Engineering, 9000-390 Funchal, Madeira, Portugal \\ b Mariculture Center of Calheta, Vila da Calheta, 9370-133 Calheta, Madeira, Portugal \\ c CIIMAR, Interdisciplinary Centre of Marine and Environmental Research, Rua dos Bragas 289, 4050-123 Porto, Portugal
}

\section{A R T I C L E I N F O}

\section{Article history:}

Received 21 March 2016

Received in revised form 6 July 2016

Accepted 7 July 2016

Available online 15 July 2016

\section{Keywords:}

Nutrient availability

LC-PUFA

N. gaditana

R. marina

Isochrysis sp.

\begin{abstract}
A B S T R A C T
To maximize and enhance the fatty acid (FA) profiles of microalgae, it is crucial to understand the metabolic pathways that lead to high levels of the desired product. Nannochloropsis gaditana, Rhodomonas marina, and Isochrysis sp. were cultivated in media with various nutrient concentrations, and the biomass was analyzed for protein and fatty acid contents. The long chain polyunsaturated fatty acid (LC-PUFA) and protein contents were maximized in media with high nutrient concentrations. Under these conditions, the reduction in the (SFA + MUFA)/PUFA ratio (by as much as $83 \%$ ) indicated that $R$. marina and $N$. gaditana shifted preference towards PUFA synthesis. The $\sum \omega 3 / \sum \omega 6$ ratio indicated that $R$. marina preferentially synthesized $\omega 3 \mathrm{FA}$ towards high nutrient concentrations (depicted by an eightfold increase) in contrast to Isochrysis sp. (which yielded a $35 \%$ reduction). In addition, the

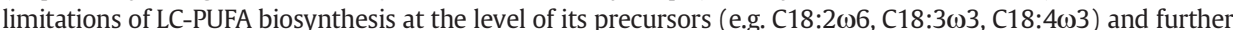
conversion to LC-PUFA as nutrients were increased, suggesting that external variations induced changes in the sets of enzymes that maintain the desaturation and elongation pathways of FA. The present study provides novel insights into the regulation of LC-PUFA biosynthesis and facilitates the modeling of microalgal FA patterns depending on the field of application.
\end{abstract}

(c) 2016 Elsevier B.V. All rights reserved.

\section{Contents}

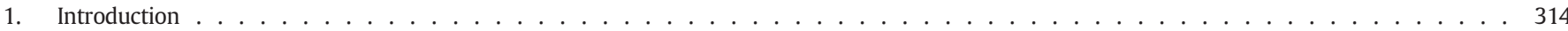

2. Materials and methods ........... 315

2.1. Algal growth and experiment design . . . . . . . . . . . . . . . . . . . . . . . . . . . . . . . . . . . . . 315

2.2. Determination of specific growth rate and fatty acid productivity . . . . . . . . . . . . . . . . . . . . . . . . . . . 315

2.3. Fatty acid determination . . . . . . . . . . . . . . . . . . . . . . . . . . . . . . . . . . . . . . .

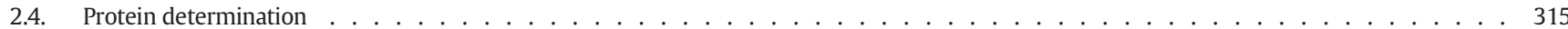

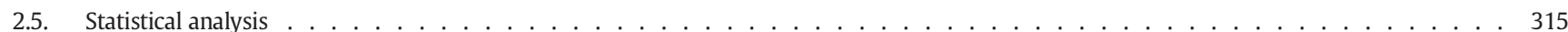

3. Results and discussion . . . . . . . . . . . . . . . . . . . . . . . . . . . . . . . . . 315

3.1. Protein and long chain polyunsaturated fatty acids (LC-PUFAs) . . . . . . . . . . . . . . . . . . . . . . 315

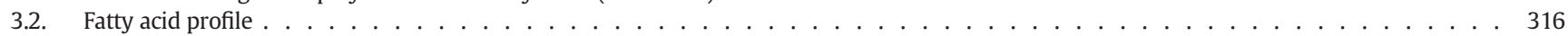

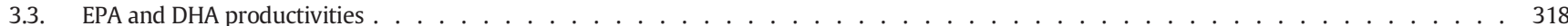

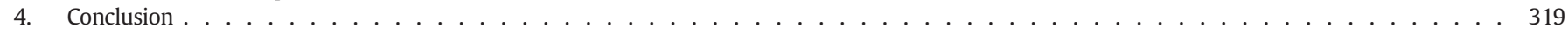

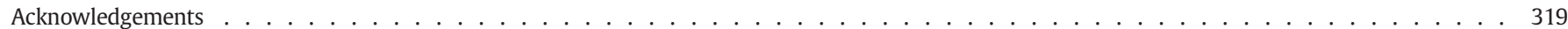

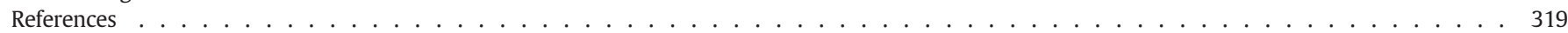

\footnotetext{
* Corresponding author.

E-mail address: ncordeiro@uma.pt (N. Cordeiro).
}

\section{Introduction}

Microalgae are fast growing organisms that produce a variety of compounds that have various commercial uses [19,25]. For instance, the synthesis of bioactive compounds like polyunsaturated fatty acids 
(PUFAs), sterols, pigments, and vitamins, makes them suitable for use in fish farming and human health [24]. In contrast, saturated and monounsaturated fatty acids, along with hydrocarbons produced by microalgal strains are suitable for biodiesel production $[13,19]$.

Long chain PUFA (LC-PUFA) play key roles as components of biological membranes and precursors of a variety of signaling molecules (e.g. leukotrienes and eicosanoids) with multiple physiological and pathological responses [7,15]. For instance, the intake of PUFA, namely omega3 $(\omega 3)$, by humans can prevent or improve cardiovascular diseases, hypertension, and arthritis [24]. Fish and their oils are considered dietary sources of $\omega 3$ LC-PUFA, particularly eicosapentaenoic (EPA - C20:5 $\omega 3$ ) and docosahexaenoic (DHA - C22:6 $\omega 3$ ) acids [1,12,23]. Nevertheless, as with humans, fish lack the ability to efficiently synthesize the $\omega 3$ or $\omega 6$ (omega 6) LC-PUFA required for normal growth and development, and must acquire these substances through their diet $[15,19,28]$.

Microalgae are the primary sources of PUFA in the marine food chain. They are supplemented with zooplankton and other aquatic organisms and used as live feeds in marine hatcheries [19,34]. Consequently, fatty acid (FA) composition is an important parameter in the selection of microalgal strains for aquaculture [10]. Some of the most commonly used strains are Nannochloropsis sp. (EPA - producers) and Isochrysis sp. [Isochrysis aff. Galbana: DHA - producer; Isochrysis galbana (Parke): rich in both EPA and DHA] [10,15,22].

Although these photosynthetic organisms naturally produce high amounts of PUFA, their FA content and composition can be enhanced by subjecting them to changes in their growth conditions [15,22]. In this regard, manipulation of environmental parameters, such as the composition of the growth medium or the presence of critical media components could influence the nature, amount, and composition of the desired FA [16]. The aim of the present study was to assess the effects of growth media on the qualitative and quantitative characteristics of FA contents, and on the enhancement of EPA and DHA contents in three marine microalgae - Nannochloropsis gaditana, Rhodomonas marina, and Isochrysis sp. (used as feed in aquaculture), by applying a range of various nutrient concentrations.

\section{Materials and methods}

\subsection{Algal growth and experiment design}

The Isochrysis sp., $R$. marina, and $N$. gaditana were supplied by the Mariculture Center of Calheta (Madeira, Portugal). Each microalga strain was cultured in $500 \mathrm{~mL}$ of enriched seawater, with commercial culture medium Nutribloom Plus (Necton, Portugal). Five volumes: 250 (T1), 500 (T2), 1000 (T3), 2000 (T4), and 4000 (T5) $\mu \mathrm{L}$ of nutrient solution $\mathrm{L}^{-1}$ were used in the preparation of the growth media. The components and respective concentrations are presented in Table 1. Aerated cultures were maintained at $23^{\circ} \mathrm{C}$, with a photoperiod of $18: 6 \mathrm{~h}$ light/dark cycles, at a light intensity of $52 \mu \mathrm{mol} \mathrm{m} \mathrm{m}^{-2} \mathrm{~s}^{-1}$. The microalgae were harvested in the stationary phase. More detailed information on algal growth and the experimental design is outlined in Fernandes et al. [9].

\subsection{Determination of specific growth rate and fatty acid productivity}

After harvest in stationary phase, the productivity of fatty acids was estimated according to the methods of Hoffmann et al. [13], by the following equation:

$P_{x}=r \times c_{x}$

where $P_{x}$ represents the productivity $\left(\mathrm{mg} \mathrm{g}^{-1} \mathrm{~d}^{-1}\right)$ of a specific FA $(x), r$ is the growth rate $\left(\mathrm{d}^{-1}\right)$, and $c_{x}$ is the concentration of the fatty acid $\left(\mathrm{mg} \mathrm{g}^{-1}\right)$. The results represented the mean values \pm standard deviation (SD).
Table 1

Growth media composition ( $\mathrm{mg} \mathrm{L}^{-1}$ ) from treatments $\mathrm{T} 1$ to $\mathrm{T}$.

\begin{tabular}{lccccc}
\hline \multirow{2}{*}{ Component } & \multicolumn{6}{l}{ Concentration in final growth medium $\left(\mathrm{mg} \mathrm{L}^{-1}\right)$} \\
\cline { 2 - 6 } & $\mathrm{T} 1$ & $\mathrm{~T} 2$ & $\mathrm{~T} 3$ & $\mathrm{~T} 4$ & \multicolumn{1}{c}{$\mathrm{T} 5$} \\
\hline $\mathrm{NaNO}_{3}$ & 43 & 85 & 170 & 340 & 680 \\
$\mathrm{KH}_{2} \mathrm{PO}_{4}$ & 3 & 7 & 14 & 27 & 54 \\
$\mathrm{EDTA}$ & 2 & 4 & 8 & 15 & 31 \\
$\mathrm{FeCl}_{3} \cdot 6 \mathrm{H}_{2} \mathrm{O}$ & 1 & 3 & 5 & 11 & 22 \\
$\mathrm{ZnCl}_{2}$ & 0.03 & 0.07 & 0.14 & 0.27 & 0.54 \\
$\mathrm{ZnSO}_{4}$ & 0.07 & 0.14 & 0.29 & 0.57 & 1.15 \\
$\mathrm{MnCl}_{2} \cdot 2 \mathrm{H}_{2} \mathrm{O}$ & 0.04 & 0.08 & 0.16 & 0.32 & 0.65 \\
$\mathrm{Na}_{2} \mathrm{MoO}_{4} \cdot 2 \mathrm{H} \mathrm{O}$ & 0.01 & 0.01 & 0.02 & 0.05 & 0.10 \\
$\mathrm{CoCl}_{2} \cdot 6 \mathrm{H} 2 \mathrm{O}$ & 0.01 & 0.01 & 0.02 & 0.05 & 0.10 \\
$\mathrm{CuSO}_{4} \cdot 5 \mathrm{H}_{2} \mathrm{O}$ & 0.01 & 0.01 & 0.03 & 0.05 & 0.10 \\
$\mathrm{MgSO}_{4} \cdot 7 \mathrm{H}_{2} \mathrm{O}$ & 0.12 & 0.25 & 0.49 & 0.98 & 1.97 \\
Vitamins $_{\text {Tiamine }}$ & & & & & \\
$\mathrm{Biotin}_{\mathrm{B}}$ & 0.01 & 0.02 & 0.04 & 0.07 & 0.14 \\
\hline
\end{tabular}

\subsection{Fatty acid determination}

The fatty acid composition of dried algal biomass was determined and expressed as FA methyl esters (FAME), as previously described by Lepage and Roy [20], and modified according to the methods of Cohen et al. [6]. Briefly, FAs were converted to FAMEs by adding a mixture of ethyl acetate-methanol $(1: 19 \mathrm{v} / \mathrm{v})$ to dry biomass that was then left at $80{ }^{\circ} \mathrm{C}$ for $1 \mathrm{~h}$, and then further extracted with heptane. FAMEs were analyzed by gas chromatography (Agilent HP 6890) equipped with a mass selective detector (Agilent 5973) and a capillary column DB-225J\&W (30 $\mathrm{m} \times 0.25 \mathrm{~mm}$ inner diameter, $0.15 \mu \mathrm{m}$ film thickness) (Agilent). The chromatographic conditions were as follows: initial temperature of the oven was $35^{\circ} \mathrm{C}$ for $0.5 \mathrm{~min}$; was increased by $25^{\circ} \mathrm{C} \mathrm{min}-1$ to $195^{\circ} \mathrm{C}$; followed by $3^{\circ} \mathrm{C} \min ^{-1}$ to $205^{\circ} \mathrm{C}$; and $8{ }^{\circ} \mathrm{C} \mathrm{min}^{-1}$ until reaching the final temperature of $230{ }^{\circ} \mathrm{C}$ for $3 \mathrm{~min}$. The temperature of the injector was $250{ }^{\circ} \mathrm{C}$, that of the transfer line, $280{ }^{\circ} \mathrm{C}$; and the split ratio was $1: 100$. Helium was used as the carrier gas, with a flow rate of $2.6 \mathrm{~mL} \mathrm{~min}^{-1}$. The identification of FAMEs was made by comparison of the retention times and mass spectra fragmentation to those of known standards (bacterial acid methyl esters CP mix and Supelco 37 component FAME mix). At least two replicates were performed for each gas chromatography analysis, and the results represented the mean values \pm standard deviation (SD) of FAME expressed in $\mathrm{mg} \mathrm{g}^{-1}$ of biomass dry weight (DW). The internal standard used was heneicosanoic acid (C21:0). The chemicals were all of analytical grade and used as received.

\subsection{Protein determination}

Total protein was assessed by multiplying the nitrogen content by 6.25, as described by Kim et al. [18]. Determination of the nitrogen content was performed with an elemental analyzer, TruSpec 630-200-200.

\subsection{Statistical analysis}

Statistical analysis of the data was carried out using the IBM SPSS Statistics 23 software. Differences in growth media nutrient concentrations between treatments were assessed by one-way analysis of variance (ANOVA), followed by a Scheffe's post hoc analysis; p-values of $<0.05$ were considered statistically significant.

\section{Results and discussion}

\subsection{Protein and long chain polyunsaturated fatty acids (LC-PUFAs)}

Microalgae are natural sources of protein and LC-PUFA, namely EPA and DHA, for organisms on higher levels of marine food webs [3]. EPA 
and DHA are crucial for the maintenance of biomembranes and cellular functions (e.g. cell signaling), whereas proteins are involved in primary metabolism as biological catalysts of important reactions for cell growth $[21,30,32]$. Fig. 1 shows the effects of nutrient availability on protein and FA contents.

In N. gaditana treatments T1 to T4, EPA and protein contents presented similar increasing patterns with respect to nutrient concentration (Fig. 1a). In T5 however, the EPA content was reduced by half, in contrast to the protein content that remained constant. This might suggest that when the growth medium nutrient concentration is high, $N$. gaditana responds by accumulating nitrogen-related metabolites (proteins) and possibly by altering the membrane properties associated with EPA levels $[4,29]$.

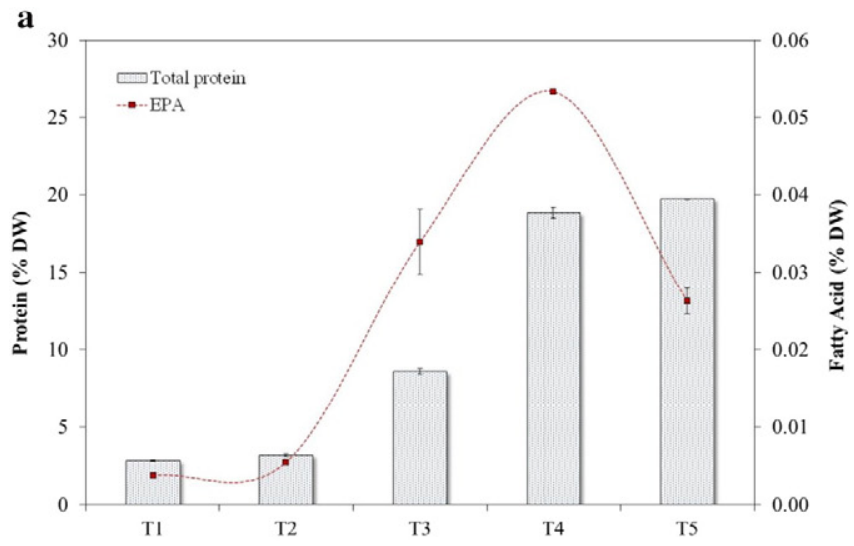

b

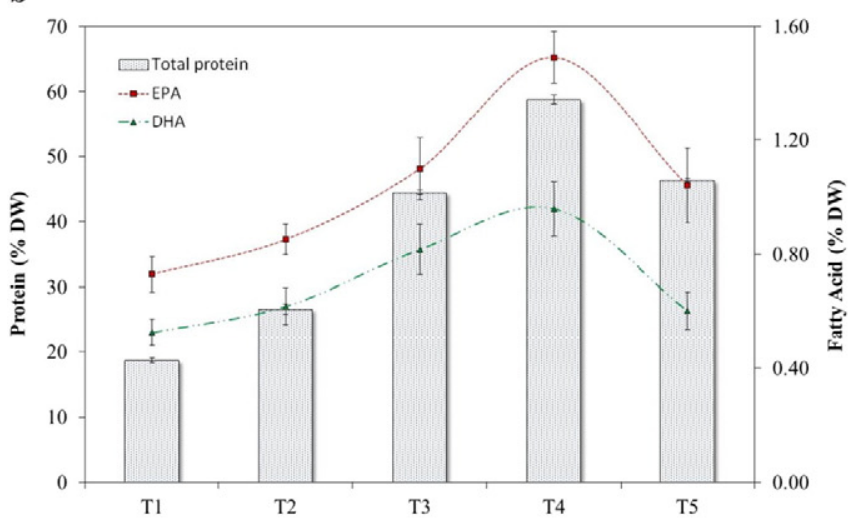

c

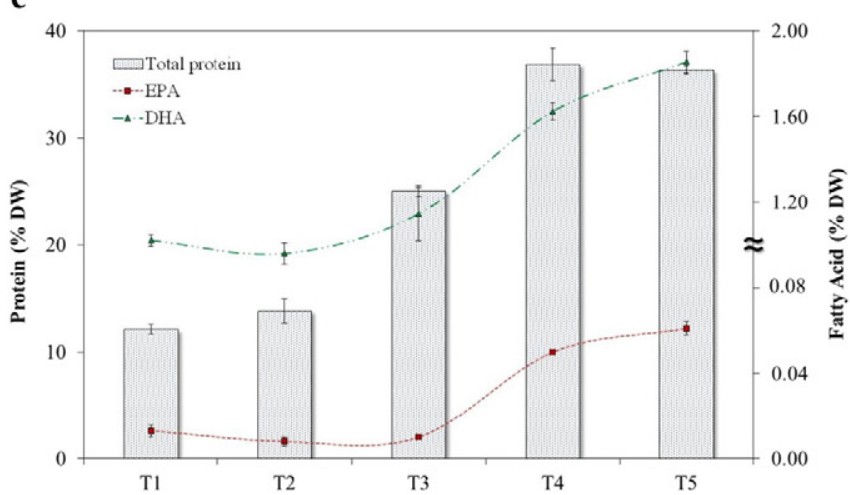

Fig. 1. The effect of growth media nutrient concentration on protein, and eicosapentaenoic acid (EPA) and docosahexaenoic acid (DHA) contents on dry biomass weight (DW) of (a) N. gaditana, (b) R. marina and (c) Isochrysis sp.
R. marina exhibited an enhancement of EPA, DHA, and protein contents, with the increase in nutrient availability from $\mathrm{T} 1$ to $\mathrm{T} 4$ reaching a saturation point in the latter (Fig. 1b). Further nutrient input (T5) seemed to be detrimental to this microalga. In Isochrysis sp., biomolecules presented a similar trend with respect to nutrient concentrations, increasing with further nutrient input (Fig. 1c.).

Several factors are known to influence the activity of fatty acid elongases and desaturases - sets of enzymes that define the degree of unsaturation and chain length of FA - namely, the availability of vitamins and inorganic co-factors that can enhance or inhibit the activity of these enzymes [7]. For instance, nitrogen and sulfur are two essential components of proteins, vitamins, and coenzymes, whereas iron is a key element of the catalytic center of desaturases [2,11]. Thus, these observations suggest that higher nutrient availability comprising high levels of macronutrients and micronutrients, enhanced the quantity (evidenced by protein content) and/or activity of desaturases and elongases. Feng et al. [8] and Kaye et al. [17] studied the effects of nitrogen concentration on enzymes involved in the LC-PUFA pathway and concluded that unsaturated FA, particularly PUFA, increases with nitrogen supplementation and expression of the enzymes involved in LC-PUFA biosynthesis is down-regulated by nitrogen depletion.

The reduction observed in LC-PUFA levels in T5 for $N$. gaditana and $R$. marina might be related to increased salinity in the external environment. Therefore, the reduction in LC-PUFA content might indicate a reduction in membrane fluidity and permeability (related to the degree of unsaturation of the membrane) as a stress response to increased intracellular osmotic pressure, thereby preventing the diffusion of potentially harmful ions into the cell [33].

\subsection{Fatty acid profile}

According to Renaud et al. [26], LC-PUFAs are associated with high growth rates of aquaculture organisms. Knowing that the FA composition of microalgae varies with environmental factors such as nutrient availability, an attempt was made to improve the FA content by inducing changes in nutrient concentration and exploiting their physiological potential as high productivity strains $[3,15]$.

Results from the experiments show that the FA composition of $N$. gaditana varied among the various nutrient availabilities (Table 2.).

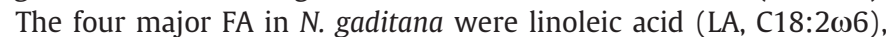
alpha linolenic acid (ALA, C18:3 133 ), palmitic acid (C16:0), and monounsaturated stearic acid (C18:1). Monounsaturated stearic acid was replaced by hexadecatrienoic acid (C16:3 13$)$ in T3, and by monounsaturated palmitic acid (C16:1) in T4 and T5. In N. gaditana, the major FA accounted for $75-89 \%$ of total FA.

In $R$. marina, nutrient availability in the growth medium induced a shift in the major FA detected (Table 3 ). In T1 and T2 for R. marina, the major FA detected were C16:0, LA, ALA, and stearidonic acid

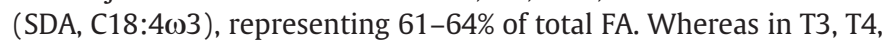
and T5, C16:0 and LA fatty acids were replaced by DHA and EPA, as predominant FA that together with ALA and SDA accounted for $73-79 \%$ of total FA.

Saturated fatty acids (SFAs) and monounsaturated fatty acids (MUFAs) are produced by de novo FA synthesis in the chloroplast, thereby providing the substrates needed for PUFA biosynthesis in the endoplasmic reticulum $[4,15]$. The experiments conducted on $N$. gaditana and $R$. marina, as evidenced by the (SFA + MUFA)/PUFA ratio, showed a shift in SFA and MUFA production towards PUFA synthesis as nutrient availability increased. Overall, the values observed for the (SFA + MUFA)/PUFA ratio in the marine microalgae studied were below 1 , with the exception of $N$. gaditana in $\mathrm{T} 1$ and $\mathrm{T} 2$ with ratios of 2.81 and 1.30 , respectively.

Previous studies have shown that $\mathrm{CO}_{2}$ levels affect the desaturation of FA [27,31]. For instance, an increase in PUFA was reportedly associated with lower $\mathrm{CO}_{2}$ availability, whereas increased $\mathrm{CO}_{2}$ availability was 
Table 2

Fatty acid profile of $N$. gaditana cultured under different nutrient concentrations.

\begin{tabular}{|c|c|c|c|c|c|}
\hline \multirow[t]{2}{*}{ Fatty acids ( $\left.\mathrm{mg} \mathrm{g}^{-1} \mathrm{DW}\right)$} & \multicolumn{5}{|l|}{ Treatment } \\
\hline & $\mathrm{T} 1$ & $\mathrm{~T} 2$ & T3 & $\mathrm{T} 4$ & $\mathrm{~T} 5$ \\
\hline C14:0 & $0.07 \pm 0.00^{\mathrm{ab}}$ & $0.06 \pm 0.00^{\mathrm{a}}$ & $0.11 \pm 0.02^{\mathrm{b}}$ & $0.19 \pm 0.02^{\mathrm{c}}$ & $0.22 \pm 0.02^{\mathrm{c}}$ \\
\hline $\mathrm{C} 16: 0$ & $1.84 \pm 0.02^{\mathrm{a}}$ & $1.25 \pm 0.03^{\mathrm{b}}$ & $1.81 \pm 0.02^{\mathrm{a}}$ & $2.79 \pm 0.11^{\mathrm{c}}$ & $3.20 \pm 0.11^{\mathrm{d}}$ \\
\hline C18:0 & $0.05 \pm 0.01^{\mathrm{a}}$ & $0.03 \pm 0.00^{\mathrm{a}}$ & $0.02 \pm 0.00^{\mathrm{a}}$ & $0.03 \pm 0.00^{\mathrm{a}}$ & $0.31 \pm 0.04^{\mathrm{b}}$ \\
\hline Total - SFA ${ }^{2}$ & $1.98 \pm 0.03^{\mathrm{a}}$ & $1.36 \pm 0.04^{\mathrm{b}}$ & $2.00 \pm 0.02^{\mathrm{a}}$ & $3.12 \pm 0.13^{c}$ & $3.84 \pm 0.19 d$ \\
\hline $\mathrm{C} 16: 1^{1}$ & $0.18 \pm 0.01^{\mathrm{a}}$ & $0.20 \pm 0.03^{\mathrm{a}}$ & $0.76 \pm 0.04^{b}$ & $2.10 \pm 0.12^{\mathrm{c}}$ & $1.94 \pm 0.27^{c}$ \\
\hline $\mathrm{C} 18: 1^{1}$ & $2.73 \pm 0.04^{\mathrm{a}}$ & $1.01 \pm 0.02^{\mathrm{b}}$ & $0.42 \pm 0.03^{c}$ & $0.50 \pm 0.05^{\mathrm{c}}$ & $0.73 \pm 0.12^{\mathrm{d}}$ \\
\hline Total - MUFA ${ }^{2}$ & $2.91 \pm 0.04^{\mathrm{a}}$ & $1.21 \pm 0.06^{\mathrm{b}}$ & $1.17 \pm 0.05^{\mathrm{b}}$ & $2.60 \pm 0.17^{\mathrm{a}}$ & $2.67 \pm 0.39^{a}$ \\
\hline $\mathrm{C} 16: 3 \omega 3$ & $0.26 \pm 0.01^{\mathrm{a}}$ & $0.35 \pm 0.01^{\mathrm{a}}$ & $1.11 \pm 0.08^{\mathrm{b}}$ & $0.97 \pm 0.18^{\mathrm{bc}}$ & $0.80 \pm 0.02^{c}$ \\
\hline $\mathrm{C} 18: 2 \omega 6$ & $0.66 \pm 0.03^{\mathrm{a}}$ & $0.58 \pm 0.03^{\mathrm{a}}$ & $1.63 \pm 0.04^{b}$ & $2.27 \pm 0.18^{c}$ & $2.66 \pm 0.01^{\mathrm{d}}$ \\
\hline $\mathrm{C} 18: 3 \omega 3$ & $0.70 \pm 0.02^{\mathrm{a}}$ & $0.89 \pm 0.02^{\mathrm{a}}$ & $2.82 \pm 0.17^{b}$ & $3.00 \pm 0.54^{\mathrm{b}}$ & $2.45 \pm 0.18^{b}$ \\
\hline $\mathrm{C} 18: 4 \omega 3$ & n.d. & n.d. & $0.04 \pm 0.00^{\mathrm{a}}$ & $0.01 \pm 0.00^{\mathrm{b}}$ & $0.01 \pm 0.00^{\mathrm{b}}$ \\
\hline C20:5 $\omega 3$ - EPA & $0.04 \pm 0.00^{\mathrm{a}}$ & $0.05 \pm 0.00^{\mathrm{a}}$ & $0.34 \pm 0.04^{b}$ & $0.53 \pm 0.00^{c}$ & $0.26 \pm 0.02^{\mathrm{d}}$ \\
\hline Total - PUFA ${ }^{2}$ & $1.74 \pm 0.06^{\mathrm{a}}$ & $1.98 \pm 0.07^{\mathrm{a}}$ & $6.46 \pm 0.34^{b}$ & $7.54 \pm 1.17^{\mathrm{b}}$ & $7.19 \pm 0.14^{\mathrm{b}}$ \\
\hline$\sum \omega 3$ & $1.00 \pm 0.03^{\mathrm{a}}$ & $1.29 \pm 0.03^{\mathrm{a}}$ & $4.31 \pm 0.30^{\mathrm{b}}$ & $4.39 \pm 0.93^{b}$ & $3.52 \pm 0.22^{\mathrm{b}}$ \\
\hline$\sum \omega 6$ & $0.66 \pm 0.03^{\mathrm{a}}$ & $0.58 \pm 0.03^{a}$ & $1.63 \pm 0.04^{\mathrm{b}}$ & $2.27 \pm 0.18^{c}$ & $2.66 \pm 0.01^{d}$ \\
\hline$\sum \omega 3 / \sum \omega 6$ & $1.51 \pm 0.04^{\mathrm{a}}$ & $2.22 \pm 0.09^{b}$ & $2.64 \pm 0.12^{c}$ & $1.92 \pm 0.27^{\mathrm{b}}$ & $1.33 \pm 0.08^{\mathrm{a}}$ \\
\hline$\omega 3$ LC-PUFA & $0.04 \pm 0.00^{\mathrm{a}}$ & $0.05 \pm 0.00^{\mathrm{a}}$ & $0.34 \pm 0.04^{\mathrm{b}}$ & $0.53 \pm 0.00^{c}$ & $0.26 \pm 0.02^{\mathrm{d}}$ \\
\hline$(\mathrm{SFA}+\mathrm{MUFA}) / \mathrm{PUFA}$ & $2.81 \pm 0.09^{\mathrm{a}}$ & $1.30 \pm 0.02^{\mathrm{b}}$ & $0.49 \pm 0.03^{c}$ & $0.77 \pm 0.15^{\mathrm{d}}$ & $0.91 \pm 0.10^{\mathrm{d}}$ \\
\hline Total $^{2}$ & $6.62 \pm 0.08^{\mathrm{a}}$ & $4.54 \pm 0.15^{\mathrm{b}}$ & $9.63 \pm 0.32^{c}$ & $13.26 \pm 1.13^{\mathrm{d}}$ & $13.70 \pm 0.44^{c}$ \\
\hline
\end{tabular}

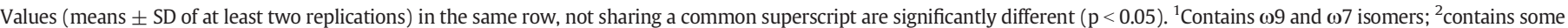

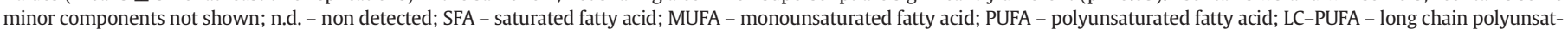
urated fatty acid.

related to increased SFA over unsaturated FA [27,31]. As the inorganic carbon source (atmospheric $\mathrm{CO}_{2}$ ) remained constant, the present findings suggest that the changes observed could be attributed to the carbon and mineral substrate ratio that was reduced as nutrient input was increased.

The FA profile of Isochrysis sp. varied across treatments (Table 4). For these microalgae, the major FA detected were myristic acid (C14:0), monounsaturated stearic acid (C18:1), SDA, and DHA, accounting for over $70 \%$ of the total FA among all treatments. Isochrysis sp. and R. marina yielded the highest LC-PUFA contents, with SDA as the major fatty acid. However, the FA profiles of Isochrysis sp. and R. marina presented qualitative and quantitative differences.

In microalgae, two pathways can lead to LC-PUFA production. LA is the common precursor that is converted to ALA or gamma linolenic

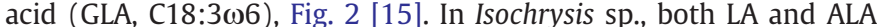
were present at concentrations below $10 \mathrm{mg} \mathrm{g}^{-1}$ of dry biomass, in contrast to the highly unsaturated final product, DHA. These results are consistent with those previously reported by Huerlimann et al. [15] for Isochrysis aff. Galbana (T. ISO). Moreover, the highest LA levels observed in $\mathrm{T} 1$ and $\mathrm{T} 2$ for $R$. marina could be attributed to the downregulation of desaturases and elongases, induced by low nutrient availability. This finding is supported by a reduction in $\omega 3$ LC-PUFA content and increase in intermediate fatty acid concentration. The present results suggest that for N. gaditana, the media used were not the most appropriate for LC-PUFA accumulation, since the highest levels of $\omega 3$ and $\omega 6$ FA obtained were LA and ALA. These FAs were previously reported as substrates for desaturation and elongation pathways that lead to LC-PUFA synthesis [15].

Table 3

Fatty acid composition of $R$. marina according to nutrient concentration.

\begin{tabular}{|c|c|c|c|c|c|}
\hline \multirow[t]{2}{*}{ Fatty acids ( $\left.\mathrm{mg} \mathrm{g}^{-1} \mathrm{DW}\right)$} & \multicolumn{5}{|l|}{ Treatment } \\
\hline & $\mathrm{T} 1$ & $\mathrm{~T} 2$ & T3 & $\mathrm{T} 4$ & $\mathrm{~T} 5$ \\
\hline C14:0 & $9.43 \pm 0.73^{\mathrm{a}}$ & $7.36 \pm 1.08^{\mathrm{b}}$ & $5.32 \pm 0.42^{\mathrm{C}}$ & $4.13 \pm 0.45^{\mathrm{cd}}$ & $3.02 \pm 0.27^{\mathrm{d}}$ \\
\hline C16:0 & $22.00 \pm 1.26^{\mathrm{a}}$ & $13.00 \pm 1.45^{\mathrm{b}}$ & $3.70 \pm 0.21^{\mathrm{c}}$ & $3.15 \pm 0.28^{c}$ & $2.45 \pm 0.16^{\mathrm{c}}$ \\
\hline C18:0 & $4.04 \pm 0.26^{\mathrm{a}}$ & $1.86 \pm 0.14^{\mathrm{b}}$ & $0.32 \pm 0.02^{c}$ & $0.34 \pm 0.03^{c}$ & $0.25 \pm 0.06^{\mathrm{c}}$ \\
\hline Total - SFA ${ }^{2}$ & $42.40 \pm 2.72^{\mathrm{a}}$ & $30.62 \pm 4.01^{b}$ & $15.44 \pm 0.99^{c}$ & $8.65 \pm 0.79^{d}$ & $6.26 \pm 0.36^{\mathrm{d}}$ \\
\hline $\mathrm{C} 16: 1^{1}$ & $2.28 \pm 0.20^{\mathrm{a}}$ & $1.52 \pm 0.13^{\mathrm{bc}}$ & $1.28 \pm 0.09^{\mathrm{b}}$ & $2.22 \pm 0.26^{\mathrm{a}}$ & $1.87 \pm 0.11^{\mathrm{ac}}$ \\
\hline $\mathrm{C} 18: 1^{1}$ & $17.66 \pm 1.24^{\mathrm{a}}$ & $11.87 \pm 1.05^{\mathrm{b}}$ & $5.66 \pm 0.17^{c}$ & $5.57 \pm 0.25^{c}$ & $4.48 \pm 0.16^{c}$ \\
\hline Total - MUFA ${ }^{2}$ & $19.98 \pm 1.40^{\mathrm{a}}$ & $13.41 \pm 1.17^{b}$ & $6.94 \pm 0.19^{c}$ & $7.79 \pm 0.51^{\mathrm{c}}$ & $6.36 \pm 0.27^{c}$ \\
\hline $\mathrm{C} 18: 2 \omega 6$ & $19.30 \pm 1.33^{\mathrm{a}}$ & $12.21 \pm 0.86^{\mathrm{b}}$ & $4.02 \pm 0.09^{c}$ & $4.83 \pm 0.20^{\mathrm{c}}$ & $1.98 \pm 0.22^{\mathrm{d}}$ \\
\hline $\mathrm{C} 18: 3 \omega 3$ & $32.75 \pm 1.98^{\mathrm{a}}$ & $28.44 \pm 1.98^{b}$ & $26.88 \pm 0.39^{b c}$ & $23.82 \pm 1.12^{\mathrm{c}}$ & $16.52 \pm 0.15^{d}$ \\
\hline $\mathrm{C} 18: 4 \omega 3$ & $22.08 \pm 1.54^{\mathrm{a}}$ & $18.70 \pm 1.12^{\mathrm{b}}$ & $26.86 \pm 0.72^{c}$ & $32.53 \pm 0.66^{\mathrm{d}}$ & $23.50 \pm 0.98^{\mathrm{a}}$ \\
\hline $\mathrm{C} 20: 4 \omega 6$ - AA & $0.07 \pm 0.02^{\mathrm{ab}}$ & $0.09 \pm 0.02^{\mathrm{a}}$ & $0.01 \pm 0.00^{c}$ & $0.05 \pm 0.02^{\mathrm{bc}}$ & n.d. \\
\hline C20:5 $\omega 3$ - EPA & $7.31 \pm 0.62^{\mathrm{a}}$ & $8.52 \pm 0.54^{\mathrm{ab}}$ & $10.99 \pm 1.09^{c}$ & $14.92 \pm 0.90^{\mathrm{d}}$ & $10.41 \pm 1.31^{\mathrm{bc}}$ \\
\hline 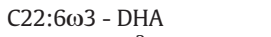 & $5.27 \pm 0.47^{\mathrm{a}}$ & $6.18 \pm 0.64^{\mathrm{a}}$ & $8.17 \pm 0.88^{\mathrm{b}}$ & $9.59 \pm 0.95^{\mathrm{b}}$ & $6.03 \pm 0.65^{\mathrm{a}}$ \\
\hline Total - PUFA ${ }^{2}$ & $87.63 \pm 5.69^{\mathrm{a}}$ & $74.61 \pm 4.01^{\mathrm{b}}$ & $77.03 \pm 2.55^{\mathrm{bc}}$ & $85.98 \pm 1.82^{\mathrm{ac}}$ & $58.46 \pm 3.28^{d}$ \\
\hline$\sum \omega 3$ & $67.41 \pm 4.52^{\mathrm{ab}}$ & $61.84 \pm 3.23^{\mathrm{ac}}$ & $72.89 \pm 2.54^{\mathrm{bd}}$ & $80.87 \pm 1.70^{\mathrm{d}}$ & $56.46 \pm 3.06^{\mathrm{c}}$ \\
\hline$\sum \omega 6$ & $20.22 \pm 1.40^{\mathrm{a}}$ & $12.77 \pm 0.87^{\mathrm{b}}$ & $4.13 \pm 0.09^{c}$ & $5.12 \pm 0.17^{c}$ & $2.00 \pm 0.22^{\mathrm{d}}$ \\
\hline$\sum \omega 3 / \sum \omega 6$ & $3.34 \pm 0.15^{\mathrm{a}}$ & $4.85 \pm 0.17^{\mathrm{a}}$ & $17.63 \pm 0.69^{b}$ & $15.81 \pm 0.40^{\mathrm{b}}$ & $28.31 \pm 1.54^{\mathrm{c}}$ \\
\hline$\omega 3$ LC-PUFA & $12.58 \pm 1.07^{a}$ & $14.71 \pm 1.18^{\mathrm{a}}$ & $19.16 \pm 1.97^{b}$ & $24.52 \pm 1.82^{c}$ & $16.44 \pm 1.96^{\mathrm{ab}}$ \\
\hline DHA/EPA & $0.72 \pm 0.02^{\mathrm{a}}$ & $0.72 \pm 0.03^{\mathrm{a}}$ & $0.74 \pm 0.01^{\mathrm{a}}$ & $0.64 \pm 0.03^{\mathrm{b}}$ & $0.58 \pm 0.01^{\mathrm{c}}$ \\
\hline$(\mathrm{SFA}+\mathrm{MUFA}) / \mathrm{PUFA}$ & $0.71 \pm 0.03^{\mathrm{a}}$ & $0.59 \pm 0.05^{\mathrm{b}}$ & $0.29 \pm 0.02^{c}$ & $0.19 \pm 0.01^{\mathrm{d}}$ & $0.22 \pm 0.01^{\mathrm{d}}$ \\
\hline Total $^{2}$ & $150.01 \pm 9.24^{\mathrm{a}}$ & $118.64 \pm 8.72^{\mathrm{b}}$ & $99.40 \pm 2.04^{c}$ & $102.43 \pm 2.34^{\mathrm{c}}$ & $71.08 \pm 3.19^{d}$ \\
\hline
\end{tabular}

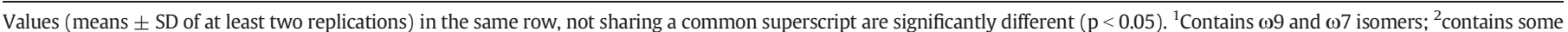

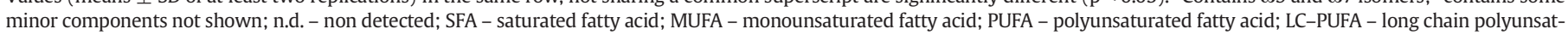
urated fatty acid. 
Table 4

Fatty acid profile of Isochrysis sp. grown under different nutrient concentration.

\begin{tabular}{|c|c|c|c|c|c|}
\hline \multirow[t]{2}{*}{ Fatty acids ( $\left.\mathrm{mg} \mathrm{g}^{-1} \mathrm{DW}\right)$} & \multicolumn{5}{|l|}{ Treatment } \\
\hline & $\mathrm{T} 1$ & $\mathrm{~T} 2$ & T3 & $\mathrm{T} 4$ & T5 \\
\hline C14:0 & $5.97 \pm 0.18^{\mathrm{a}}$ & $4.64 \pm 0.09^{b}$ & $9.48 \pm 0.69^{c}$ & $13.97 \pm 0.51^{\mathrm{d}}$ & $14.48 \pm 0.43^{\mathrm{d}}$ \\
\hline C16:0 & $3.91 \pm 0.12^{\mathrm{a}}$ & $2.98 \pm 0.10^{\mathrm{b}}$ & $5.34 \pm 0.40^{c}$ & $6.77 \pm 0.21^{\mathrm{d}}$ & $6.78 \pm 0.16^{\mathrm{d}}$ \\
\hline $\mathrm{C} 18: 0$ & $0.01 \pm 0.00^{\mathrm{a}}$ & n.d. & n.d. & $0.03 \pm 0.00^{\mathrm{b}}$ & $0.02 \pm 0.01^{\mathrm{b}}$ \\
\hline Total - SFA ${ }^{2}$ & $10.14 \pm 0.29^{a}$ & $7.71 \pm 0.14^{\mathrm{b}}$ & $15.06 \pm 1.10^{c}$ & $21.26 \pm 0.65^{d}$ & $21.89 \pm 0.61^{\mathrm{d}}$ \\
\hline $\mathrm{C} 16: 1^{1}$ & $3.44 \pm 0.16^{\mathrm{a}}$ & $2.36 \pm 0.20^{\mathrm{b}}$ & $4.63 \pm 0.51^{c}$ & $6.49 \pm 0.16^{\mathrm{d}}$ & $7.27 \pm 0.43^{\mathrm{d}}$ \\
\hline $\mathrm{C} 18: 1^{1}$ & $7.42 \pm 0.27^{\mathrm{a}}$ & $4.64 \pm 0.32^{\mathrm{b}}$ & $8.02 \pm 0.84^{a}$ & $9.30 \pm 0.32^{c}$ & $10.10 \pm 0.23^{c}$ \\
\hline Total - MUFA ${ }^{2}$ & $10.89 \pm 0.43^{\mathrm{a}}$ & $7.03 \pm 0.51^{\mathrm{b}}$ & $12.68 \pm 1.34^{\mathrm{a}}$ & $16.12 \pm 0.50^{c}$ & $17.72 \pm 0.62^{c}$ \\
\hline$C 16: 3 \omega 3$ & $0.07 \pm 0.02^{\mathrm{ab}}$ & $0.08 \pm 0.02^{\mathrm{ab}}$ & $0.01 \pm 0.00^{\mathrm{a}}$ & $0.15 \pm 0.04^{\mathrm{bc}}$ & $0.17 \pm 0.05^{\mathrm{c}}$ \\
\hline $\mathrm{C} 18: 2 \omega 6$ & $2.24 \pm 0.15^{\mathrm{ab}}$ & $1.81 \pm 0.20^{\mathrm{a}}$ & $2.91 \pm 0.52^{\mathrm{b}}$ & $6.30 \pm 0.22^{c}$ & $7.33 \pm 0.23^{d}$ \\
\hline $\mathrm{C} 18: 3 \omega 3$ & $3.10 \pm 0.10^{\mathrm{a}}$ & $2.88 \pm 0.23^{\mathrm{a}}$ & $5.47 \pm 0.47^{\mathrm{b}}$ & $7.64 \pm 0.15^{c}$ & $8.49 \pm 0.25^{\mathrm{d}}$ \\
\hline $\mathrm{C} 18: 4 \omega 3$ & $14.11 \pm 0.41^{\mathrm{a}}$ & $14.27 \pm 0.62^{\mathrm{a}}$ & $25.24 \pm 1.33^{\mathrm{b}}$ & $35.43 \pm 0.62^{c}$ & $38.90 \pm 0.73^{d}$ \\
\hline C20:5 $\omega 3$ - EPA & $0.13 \pm 0.03^{\mathrm{a}}$ & $0.08 \pm 0.02^{\mathrm{a}}$ & $0.10 \pm 0.01^{\mathrm{a}}$ & $0.50 \pm 0.01^{\mathrm{b}}$ & $0.61 \pm 0.03^{c}$ \\
\hline 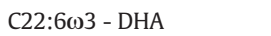 & $10.20 \pm 0.27^{\mathrm{ab}}$ & $9.59 \pm 0.49^{a}$ & $11.44 \pm 1.26^{\mathrm{b}}$ & $16.25 \pm 0.39^{c}$ & $18.54 \pm 0.51^{\mathrm{d}}$ \\
\hline Total - PUFA ${ }^{2}$ & $30.10 \pm 0.99^{\mathrm{a}}$ & $28.86 \pm 1.59^{a}$ & $45.44 \pm 3.28^{b}$ & $67.80 \pm 1.44^{c}$ & $76.09 \pm 1.92^{\mathrm{d}}$ \\
\hline$\sum \omega 3$ & $27.61 \pm 0.78^{a}$ & $26.90 \pm 1.34^{\mathrm{a}}$ & $42.25 \pm 2.69^{b}$ & $59.91 \pm 1.08^{c}$ & $66.66 \pm 1.42^{\mathrm{d}}$ \\
\hline$\sum \omega 6$ & $2.31 \pm 0.17^{\mathrm{ab}}$ & $1.87 \pm 0.23^{\mathrm{a}}$ & $2.92 \pm 0.52^{\mathrm{b}}$ & $7.20 \pm 0.30^{c}$ & $8.57 \pm 0.38^{d}$ \\
\hline$\sum \omega 3 / \sum \omega 6$ & $11.99 \pm 0.56^{\mathrm{a}}$ & $14.52 \pm 1.10^{\mathrm{b}}$ & $14.68 \pm 1.91^{\mathrm{b}}$ & $8.33 \pm 0.21^{\mathrm{c}}$ & $7.79 \pm 0.19^{c}$ \\
\hline$\omega 3$ LC-PUFA & $10.33 \pm 0.30^{\mathrm{ab}}$ & $9.67 \pm 0.50^{\mathrm{a}}$ & $11.53 \pm 1.28^{\mathrm{b}}$ & $16.69 \pm 0.50^{c}$ & $19.10 \pm 0.60^{\mathrm{d}}$ \\
\hline DHA/EPA & $83.85 \pm 16.71^{\mathrm{a}}$ & $119.35 \pm 19.11^{\mathrm{ab}}$ & $134.44 \pm 30.34^{\mathrm{b}}$ & $33.14 \pm 0.59^{c}$ & $30.66 \pm 1.32^{c}$ \\
\hline$(\mathrm{SFA}+\mathrm{MUFA}) / \mathrm{PUFA}$ & $0.70 \pm 0.01^{\mathrm{a}}$ & $0.51 \pm 0.01^{\mathrm{b}}$ & $0.61 \pm 0.02^{\mathrm{c}}$ & $0.55 \pm 0.01^{\mathrm{d}}$ & $0.52 \pm 0.01^{\mathrm{bd}}$ \\
\hline Total $^{2}$ & $51.13 \pm 1.49^{a}$ & $43.60 \pm 2.14^{b}$ & $73.18 \pm 5.14^{c}$ & $105.18 \pm 1.81^{d}$ & $115.70 \pm 2.98^{\mathrm{e}}$ \\
\hline
\end{tabular}

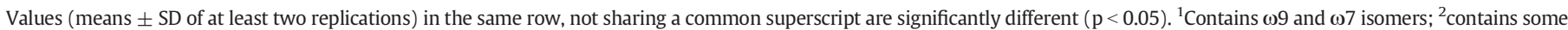

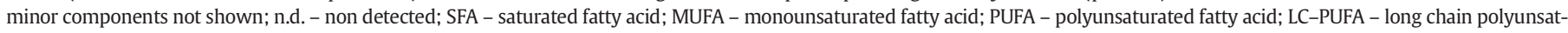
urated fatty a.

The three marine microalgae under investigation yielded $\sum \omega 3 / \sum \omega 6$ ratios $>1$, independently of the growth medium nutrient concentration. This suggests that the $\omega 3$ pathway is more active than that of $\omega 6$. For T5, $R$. marina achieved the highest ratio, comprising 28 times more $\omega 3$ FA than $\omega 6$ FA. According to Huerlimann et al. [15], this could be attributed to the substrate

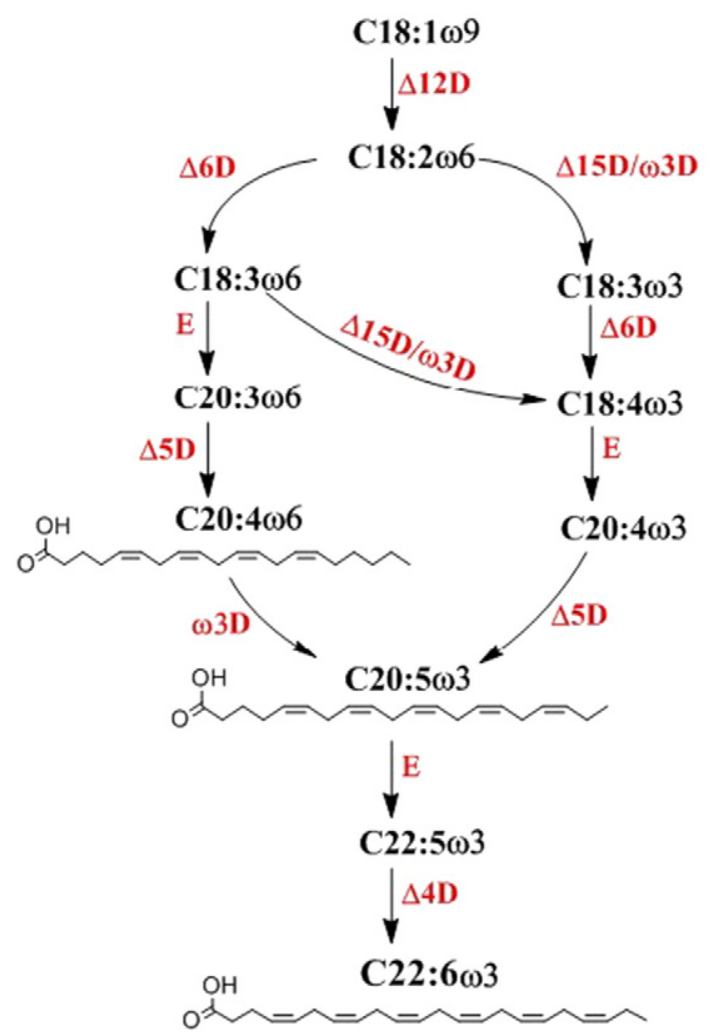

Fig. 2. Schematic representation of long chain - polyunsaturated fatty acid (LC-PUFA) biosynthesis in eukaryotic microalgae, based on Mühlroth et al. [22]. specificity of the enzyme set (namely desaturases) that link $\omega 3$ and $\omega 6$ pathways, and can be more active and preferentially diverted towards $\omega 3$ FA synthesis. Furthermore, the fatty acid profile of $R$. marina exhibited an increase in the $\sum \omega 3 / \sum \omega 6$ ratio with increasing nutrient input, whereas Isochrysis sp. exhibited the opposite trend. These findings support the assumption that the response to nutrient concentration is species-specific. They also suggest that nutrient availability affected the biosynthesis of PUFA, possibly by shifting enzyme specificity towards $\omega 6$ FA synthesis in Isochrysis sp., and $\omega 3$ FA synthesis in R. marina.

Since PUFAs are not synthesized by de novo FA synthesis and $\omega 6$ PUFA are not readily converted to $\omega 3$ PUFA in fish and humans, the levels of these biomolecules are largely determined by dietary intake [5]. Therefore, algal diets with low (SFA + MUFA)/PUFA ratios and $\sum \omega 3 / \sum \omega 6$ ratios higher than 2 are optimal for the feeding of larval and juvenile oysters [14]. For all treatments, R. marina and Isochrysis sp. exceeded the recommended minimal ratio, and their $($ SFA + MUFA)/PUFA ratios were $<1$ (Tables 2, 3, and 4 ). In contrast, the $\sum \omega 3 / \sum \omega 6$ ratio in $N$. gaditana was lower than 2 , with the exception of those subjected to treatments T2 and T3, suggesting that these treatments are suitable for the production of this microalga for aquaculture.

\subsection{EPA and DHA productivities}

The implementation of strategies that induce the accumulation of specific compounds of high value may differentially influence microalgal growth [30]. In order to improve microalgal production for commercial applications, the productivity of the cultivation systems must be considered [3].

Regarding productivity, the microalgae with the highest EPA and DHA contents, along with the highest specific growth rates were those subjected to treatment T3 for $R$. marina and $N$. gaditana, and T4 for Isochrysis sp. (Fig. 3). DHA productivity was not calculated for $N$. gaditana microalgae since it was not present in their FA profile. Since $N$. gaditana demonstrated similar EPA productivities in T3 and T4, selection of the more favorable productivity had to take costs into account. $N$. gaditana productivities were low compared to those obtained for the other microalgal strains. This was mainly due to their low FA content. 
a

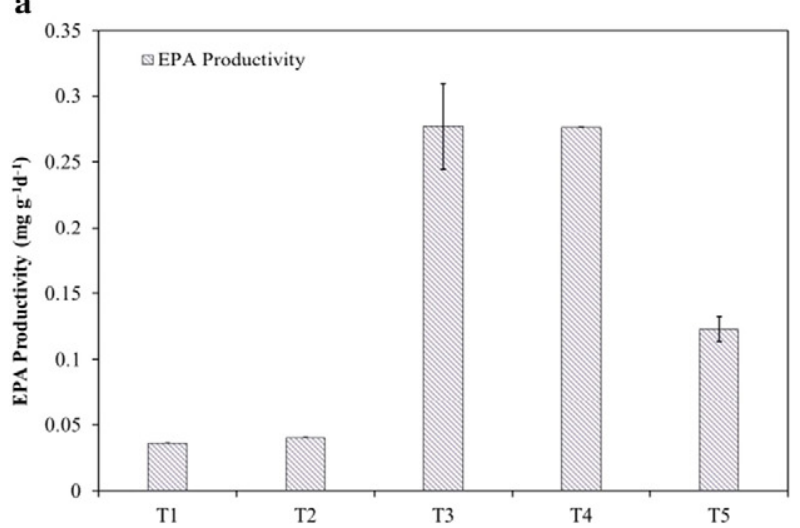

b

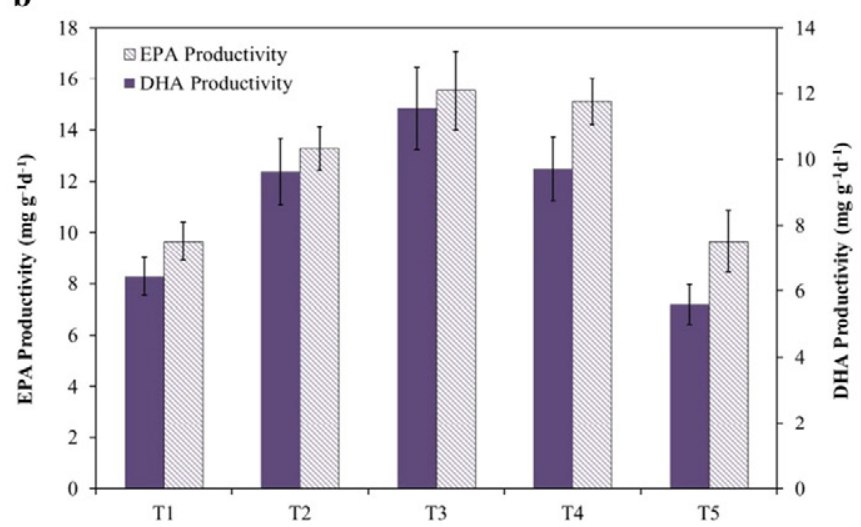

c

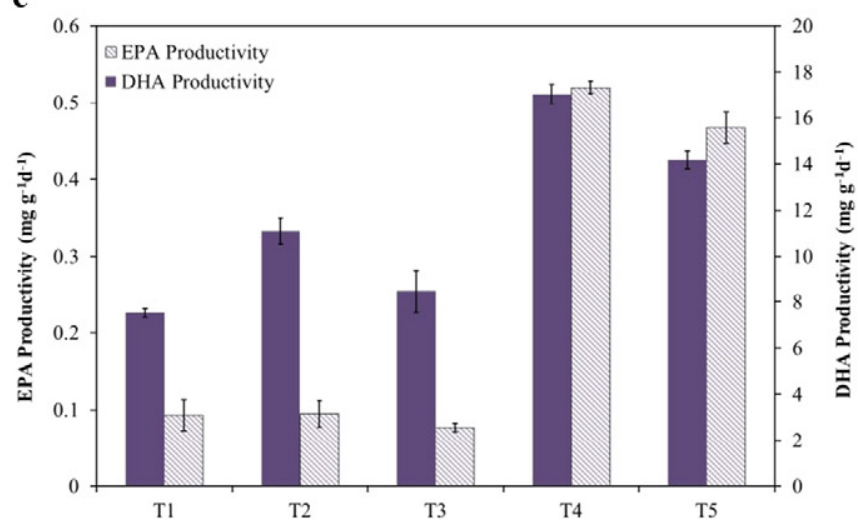

Fig. 3. Eicosapentaenoic acid (EPA) and docosahexaenoic acid (DHA) productivities for (a) $N$. gaditana, (b) R. marina and (c) Isochrysis sp. according to the nutrients media composition.

\section{Conclusion}

The mobilization of FA groups with nutrient input constitutes an advantage for the modeling of the biochemical composition of microalgae, depending on the field of application. As such, at low nutrient concentrations, the possible interruption of desaturation and elongation pathways makes the FA patterns of microalgae more suitable for biodiesel production. In contrast, high nutrient inputs enhanced the role of the enzyme sets that lead to LC-PUFA accumulation, making microalgal composition more suitable for aquaculture and nutritional supplements. The present study revealed an effective strategy to assess the metabolic pathways that lead to desirable levels of FA accumulation in three biological systems.

\section{Acknowledgements}

This study was partially supported by the Oceanic Observatory of Madeira (M1420-01-0145-FEDER-000001-Observatório Oceânico da Madeira-OOM).

\section{References}

[1] M.A. Akpinar, S. Görgün, A.E. Akpinar, A comparative analysis of the fatty acid profiles in the liver and muscles of male and female Salmo trutta macrostigma, Food Chem. 112 (2009) 6-8.

[2] J.M. Berg, J.L. Tymoczko, L. Stryer, Fatty acid metabolism, in: J.M. Berg, J.L. Tymoczko, L. Stryer (Eds.), Biochemistry, W.H. · Freeman and Company, Boston/New York 2002, pp. 601-632.

[3] M.S. Chauton, K.I. Reitan, N.H. Norsker, R. Tveterås, H.T. Kleivdal, A techno-economic analysis of industrial production of marine microalgae as a source of EPA and DHArich raw material for aquafeed: research challenges and possibilities, Aquaculture 436 (2015) 95-103.

[4] C.Y. Chen, Y.C. Chen, H.C. Huang, C.C. Huang, W.L. Lee, J.S. Chang, Engineering strategies for enhancing the production of eicosapentaenoic acid (EPA) from an isolated microalga Nannochloropsis oceanica CY2, Bioresour. Technol. 147 (2013) 160-167.

[5] G. Chen, S. Qu, Q. Wang, F. Bian, Z. Peng, Y. Zhang, H. Ge, J. Yu, N. Xuan, Y. Bi, Q. He, Transgenic expression of delta- 6 and delta-15 fatty acid desaturases enhances omega-3 polyunsaturated fatty acid accumulation in Synechocystis sp. PCC6803, Biotechnol. Biofuels 7 (2014) 1-10.

[6] Z. Cohen, A. Vonshak, A. Richmond, Effect of environmental conditions on fatty acid composition of the red alga Phorphyridium cruentum correlation to growth rate, J. Phycol. 24 (1988) 328-332.

[7] U.N. Das, Essential fatty acids: biochemistry, physiology and pathology, Biotechnol. J. 1 (2006) 420-439.

[8] D. Feng, Z. Chen, S. Xue, W. Zhang, Increased lipid production of the marine oleaginous microalgae Isochrysis zhangjiangensis (Chrysophyta) by nitrogen supplement, Bioresour. Technol. 102 (2011) 6710-6716.

[9] T. Fernandes, I. Fernandes, C.A.P. Andrade, N. Cordeiro, Marine microalgae growth and carbon partitioning as a function of nutrient availability, Bioresour. Technol. 214 (2016) 541-547.

[10] J.P. Fidalgo, A. Cid, E. Torres, A. Sukenik, C. Herrero, Effects of nitrogen source and growth phase on proximate biochemical composition, lipid classes and fatty acid profile of the marine microalga Isochrysis galbana, Aquaculture 166 (1998) 105-116.

[11] M. Giordano, J.A. Raven, Nitrogen and sulfur assimilation in plants and algae, Aquat. Bot. 118 (2014) 45-61.

[12] J.L. Guil-Guerrero, E. Venegas-Venegas, M.A. Rincón-Cervera, M.D. Suárez, Fatty acid profiles of livers from selected marine fish species, J. Food Compos. Anal. 24 (2011) 217-222.

[13] M. Hoffmann, K. Marxen, R. Schulz, K.H. Vanselow, TFA and EPA productivities of Nannochloropsis salina influenced by temperature and nitrate stimuli in turbidostatic controlled experiments, Mar. Drugs 8 (2010) 2526-2545.

[14] R. Huerlimann, R. Nys, K. Heimann, Growth, lipid content, productivity, and fatty acid composition of tropical microalgae for scale-up production, Biotechnol. Bioeng. 107 (2010) 245-257.

[15] R. Huerlimann, E.J. Steinig, H. Loxton, K.R. Zenger, D.R. Jerry, K. Heimann, Effects of growth phase and nitrogen starvation on expression of fatty acid desaturases and fatty acid composition of Isochrysis aff. galbana (T-ISO), Gene 545 (2014) 36-44.

[16] A. Karemore, R. Pal, R. Sen, Strategic enhancement of algal biomass and lipid in Chlorococcum infusionum as bioenergy feedstock, Algal Res. 2 (2013) 113-121.

[17] Y. Kaye, O. Grundman, S. Leu, A. Zarka, B. Zorin, S. Didi-Cohen, I. Khozin-Goldberg, S. Boussiba, Metabolic engineering toward enhanced LC-PUFA biosynthesis in Nannochloropsis oceanica: overexpression of endogenous $\Delta^{12}$ desaturase driven by stress-inducible promoter leads to enhanced deposition of polyunsaturated fatty acids in TAG, Algal Res. 11 (2015) 387-398.

[18] C.W. Kim, M.G. Sung, K. Nam, M. Moon, J.H. Kwon, J.W. Yang, Effect of monochromatic illumination on lipid accumulation of Nannochloropsis gaditana under continuous cultivation, Bioresour. Technol. 159 (2014) 30-35.

[19] M. Koller, A. Muhr, G. Braunegg, Microalgae as versatile cellular factories for valued products, Algal Res. 6 (2014) 52-63.

[20] G. Lepage, C.C. Roy, Direct transesterification of all classes of lipids in a onestep reaction, J. Lipid Res. 27 (1986) 114-120.

[21] L. Luo, L. Ai, T. Li, M. Xue, J. Wang, W. Li, W. Xiufeng, X. Liang, The impact of dietary DHA/EPA ratio on spawning performance, egg and offspring quality in Siberian sturgeon (Acipenser baeri), Aquaculture 437 (2015) 140-145.

[22] A. Mühlroth, K. Li, G. Røkke, P. Winge, Y. Olsen, M.F. Hohmann-Marriott, O. Vadstein, A.M. Bones, Pathways of lipid metabolism in marine algae, co-expression network, bottlenecks and candidate genes for enhanced production of EPA and DHA in species of Chromista, Mar. Drugs 11 (2013) 4662-4697.

[23] P. Nieminen, E. Westenius, T. Halonen, A.M. Mustonen, Fatty acid composition in tissues of the farmed Siberian sturgeon (Acipenser baerii), Food Chem. 159 (2014) 80-84.

[24] M.F.J. Raposo, R.M. Morais, A.M. Morais, Health applications of bioactive compounds from marine microalgae, Life Sci. 93 (2013) 479-486. 
[25] S.K. Ratha, R. Prasanna, R.B.N. Prasad, C. Sarika, D.W. Dhar, A.K. Saxena, Modulating lipid accumulation and composition in microalgae by biphasic nitrogen supplementation, Aquaculture 392-395 (2013) 69-76.

[26] S.M. Renaud, L.-V. Thinh, D.L. Parry, The gross chemical composition and fatty acid composition of 18 species of tropical Australian microalgae for possible use in mariculture, Aquaculture 170 (1999) 147-159.

[27] U. Riebesell, A.T. Revill, D.G. Holdsworth, J.K. Volkman, The effects of varying $\mathrm{CO}_{2}$ concentration on lipid composition and carbon isotope fractionation in Emiliania huxleyi, Geochim. Cosmochim. Acta 64 (2000) 4179-4192.

[28] C. Rodríguez, C. Acosta, P. Badía, J.R. Cejas, F.J. Santamaría, A. Lorenzo, Assessment of lipid and essential fatty acids requirements of black seabream (Spondyliosoma cantharus) by comparison of lipid composition in muscle and liver of wild and captive adult fish, Comp. Biochem. Physiol. B Biochem. Mol. Biol. 139 (2004) 619-629.

[29] W. Stillwell, S.R. Wassall, Docosahexaenoic acid: membrane properties of a unique fatty acid, Chem. Phys. Lipids 126 (2003) 1-27.
[30] A. Sukenik, Ecophysiological considerations in the optimization of eicosapentaenoic acid production by Nannochloropsis sp. (Eustigmatophyceae), Bioresour. Technol. 35 (1991) 263-269.

[31] G.V. Swarnalatha, N.S. Hegde, V.S. Chauhan, R. Sarada, The effect of carbon dioxide rich environment on carbonic anhydrase activity, growth and metabolite production in indigenous freshwater microalgae, Algal Res. 9 (2015) 151-159.

[32] R.C. Valentine, D.L. Valentine, Omega-3 fatty acids in cellular membranes: a unified concept, Prog. Lipid Res. 43 (2004) 383-402.

[33] X.-Q. Xu, J. Beardal, Effect of salinity on fatty acid composition of a green microalga from an antarctic hypersaline lake, Phytochemistry 45 (1997) 655-658.

[34] O.Zmora, D.J. Grosse, N. Zou, T.M. Samocha, Microalga for aquaculture: practical implications, in: A. Richmond, Q. Hu (Eds.), Handbook of Microalgal Culture: Applied Phycology and Biotechnology, John Wiley \& Sons, Chichester/West Sussex 2013, pp. 628-652. 